\title{
Alkaline Pretreatment of Sugarcane Bagasse and Filter Mud Codigested to Improve Biomethane Production
}

\author{
Zahir Talha, ${ }^{1}$ Weimin Ding, ${ }^{1}$ Esmaeil Mehryar, ${ }^{1}$ Muhammad Hassan, ${ }^{1}$ and Jinhua $\mathrm{Bi}^{2}$ \\ ${ }^{1}$ College of Engineering, Nanjing Agricultural University, Nanjing, Jiangsu 210031, China \\ ${ }^{2}$ Institute of Agricultural Resources and Environment, Jiangsu Academy of Agricultural Science, Nanjing, Jiangsu 210014, China \\ Correspondence should be addressed to Weimin Ding; wmding@njau.edu.cn
}

Received 16 April 2016; Revised 19 June 2016; Accepted 4 July 2016

Academic Editor: Wei-Hsin Chen

Copyright (c) 2016 Zahir Talha et al. This is an open access article distributed under the Creative Commons Attribution License, which permits unrestricted use, distribution, and reproduction in any medium, provided the original work is properly cited.

\begin{abstract}
To enhance the codigestion of degradation and improve biomethane production potential, sugarcane bagasse and filter mud were pretreated by sodium hydroxide $\mathrm{NaOH} 1 \mathrm{~N}$ at $100^{\circ} \mathrm{C}$ for 15,30 , and 45 minutes, respectively. Biomethane generation from 1-liter batch reactor was studied at mesophilic temperature $(37 \pm 1)^{\circ} \mathrm{C}$, solid concentrations of $6 \%$, and five levels of mixing proportion with and without pretreatment. The results demonstrate that codigestion of filter mud with bagasse produces more biomethane than fermentation of filter mud as single substrate; even codigested substrate composition presented a better balance of nutrients $(\mathrm{C} / \mathrm{N}$ ratio of 24.70) when codigestion ratio between filter mud and bagasse was $25: 75$ in comparison to filter mud as single substrate (C/N ratio 9.68). All the pretreatments tested led to solubilization of the organic matter, with a maximum lignin reduction of $86.27 \%$ and cumulative yield of biomethane $\left(195.8 \mathrm{~mL} \cdot \mathrm{gVS}^{-1}\right.$, digestion of pretreated bagasse as single substrate) obtained after 45 minutes of cooking by $\mathrm{NaOH} 1 \mathrm{~N}$ at $100^{\circ} \mathrm{C}$. Under this pretreatment condition, significant increase in cumulative methane yield was observed $\left(126.2 \mathrm{~mL} \cdot \mathrm{gVS}^{-1}\right)$ at codigestion ratio of $25: 75$ between filter mud and bagasse by increase of $81.20 \%$ from untreated composition.
\end{abstract}

\section{Introduction}

Energy plays an important role in the national security of any given country as a fuel to power the economic engine. It is convenient to use oil, coal, and natural gas for our energy needs, but they are limited and by continuous and rapid use they will run out. Furthermore, they increase greenhouse gases emission into atmosphere which causes the trapping of sun's heat and contributing to global warming $[1,2]$. Ruppert has claimed that, to produce one calorie of food in the industrial world, we need to invest ten calories of oil and gas energy in the forms of fertilizer, pesticide, packaging, transportation, and running farm equipment [3].

The crisis of huge energy demand has generated more interest in the use of biomass as a potential renewable energy source that could replace fossil energy [4]. Considerable amount of waste byproduct materials is being generated through agricultural practices, mainly from various agrobased industries. Agroindustrial biomass such as sugar industry waste is an inexpensive, renewable, abundant, and rich-in-energy potential. Unfortunately, much of the biomass is often disposed of by burning, which is not restricted to developing countries alone [5].

Sugarcane bagasse is a plentiful byproduct obtained from the sugar industry, a lignocellulosic, residual material derived after the extraction of cane juice which corresponds to about $25 \%$ of the total processed sugarcane [6]. It is almost completely burnt by sugar factories themselves as fuel for boilers [7]. Recently, more efforts have been directed toward more efficient utilization of sugarcane bagasse as a raw material for pulp and paper production, boards, animal feed, and products based on fermentation [8]. Like most agricultural residues, bagasse is rich in soluble sugar, cellulose, hemicellulose, and lignin, which promotes research capabilities on bioconversion processes of this material for the production of bioethanol, biogas, and other bioproducts [9]. Therefore, anaerobic digestion of sugarcane bagasse may improve its value as well as solve contamination problem [10].

Filter mud which is also called filter-cake is a solid residue obtained from sugarcane juice before crystallization of sugar. The availability of filter mud is about $3-7 \%$ of total crushed cane [11], while the chemical composition depends on many 
factors including the cane variety, soil condition, nutrients applied in the field, process of clarification adopted, and other environmental factors [1]. Moreover, in some sugar industries, filter mud is disposed as garbage, or used as fertilizer, whether as raw material or by converting it into compost [12]. The feature behavior of filter mud indicates that it is highly suitable for energy production $[13,14]$. It consists of hydrocarbon, sugar, and other components, and it has a good proportion of carbon to nitrogen ratio $(\mathrm{C} / \mathrm{N})$ of approximately 10 20; these are considered as significantly attractive features for generation of bioenergy by anaerobic fermentation [15-17].

Lignocelluloses consist of three major components including cellulose, hemicellulose, and lignin. Among these constituents, cellulose and hemicelluloses are polymers of sugars and can be hydrolyzed. On the other hand, lignin forms a protective covering that limits cellulose and hemicelluloses biodegradability [18]. To improve lignocelluloses material digestibility, previous studies have focused on codigestion with another material in different proportions and/or pretreatment through various methods including mechanical, thermal, chemical, and combined measures [19, 20].

To improve the yield of biomass utilization, sugarcane bagasse has been used for biofuel production (bioethanol and biogas) by high solids fed batch saccharification and fermentation process for ethanol production, and, after evaporation, the residual obtained was used for methane production through anaerobic digestion [21]. Li et al. [10] have investigated the biogas generation from sugarcane bagasse after liquid hot water (LHW) pretreatment and $\mathrm{NaOH}$ pretreatment; they showed that the gas yield of each pretreatment group increased significantly when compared to nonpretreated group. Pretreatment by per acetic acid (PAA) under mild conditions greatly increased the enzymatic digestibility of sugarcane bagasse and the yield of reducing sugars reached $92.04 \%$ by enzymatic hydrolysis [22].

As in previous study, thermoalkaline pretreatment of filter mud $\left(100^{\circ} \mathrm{C}, \mathrm{Ca}(\mathrm{OH})_{2}\right)$ for different pretreatment times and lime loading resulted in an excess of $72 \%$ of methane yield [12]. Codigestion of sugarcane filter mud with bagasse was investigated for anaerobic digestion in a semicontinuous feeding to assess the main parameters used for large scale digesters [23]. Generation of biogas was increased significantly after mixing press mud in different proportion with sugarcane bagasse and other substrates [15].

Among all the pretreatment methods, alkaline pretreatment has widely been studied. The main advantages of the process are concluded as follows: it is efficient in removal of lignin and it gives higher yields of reducing sugars. Although lime and other hydroxides are inexpensive, pretreatment processes have a significant impact on the configuration, efficiency, and cost of biogas production. Anaerobic digestion process has milder requirements for the pretreatment of lignocellulosic biomass. For example, anaerobic digestion microbes have higher tolerances to inhibitory compounds generated in pretreatment so that detoxification is not needed. Therefore, pretreatment might be more technoeconomically feasible for incorporation into commercial anaerobic digestion [24]. Sodium hydroxide pretreatment has a long history of study as it was used in an attempt to increase the digestibility of cellulose by rumen animals. This strong base solubilizes hemicellulose and lignin significantly under certain conditions [25]. The effectiveness of pretreatment using sodium hydroxide has showed a greater degree of enzyme hydrolysis than with other alkaline pretreatments, and it has been extensively studied to improve biogas yield from lignocellulosic biomass $[24,26]$ such as rice straw [27$29]$, corn stover [30, 31], and sugarcane bagasse [22, 32, 33]. The objectives of the present study are (1) to examine the biogas production by codigestion of sugarcane bagasse and filter mud for different mixing ratios, (2) to verify the potential of $\mathrm{NaOH}$ pretreatment at $100^{\circ} \mathrm{C}$, and (3) to enhance the anaerobic digestion regarding methane yield augmentation. The effects of alkaline pretreatment time on lignin removal, chemical oxygen demand (COD) solubilization, and ammonia $\left(\mathrm{NH}_{3}-\mathrm{N}\right)$ removal have been determined for different experimental conditions.

\section{Materials and Methods}

2.1. Substrate. In this work, experiments are carried out using fresh filter mud and bagasse which were provided from the Zhanjiang Huazi Land-Reclamation Sugar Industry Co. Ltd. (Guangdong, Zhanjiang, China) during 2015 harvest season. Filter mud was air-dried, milled, and sieved to a particle size of less than $2 \mathrm{~mm}$. It was subsequently stored in plastic bags at $4^{\circ} \mathrm{C}$ until use. Bagasse was first dried by the air then by oven drying in $45^{\circ} \mathrm{C}$ for $48 \mathrm{hr}$. after that milled with a grinder and sieved to pass $5 \mathrm{~mm}$ sieve, and stored in plastic bags at vented room for further analysis and fermentation.

2.2. Pretreatment Process. The pretreatment process was conducted on a 2-liter glass flask, substrate was weighted and placed into the flask, and one-liter $\mathrm{NaOH} 1 \mathrm{~N}$ was added (solid to liquid ratio was $1: 12$ ). For thermal treatment, autoclave (Jiang Yin Bing Jiang Medical Equipment Co. Ltd.) was used. The flask was sealed with aluminum foil and autoclaved at $100^{\circ} \mathrm{C}$ and 1 bar pressure for $15 \mathrm{~min}, 30 \mathrm{~min}$, and $45 \mathrm{~min}$, respectively, similar to work of [34, 35]. After alkali pretreatment, the substrate was washed with $500 \mathrm{~mL}$ pure water, then dried with oven $45^{\circ} \mathrm{C}$ for $48 \mathrm{hr}$, and stored in sealed bags for further analysis and anaerobic fermentations.

\subsection{Batch Anaerobic Digestion}

2.3.1. Experiment Setting. The batch anaerobic digestion equipment of this study consists of two 1-liter bottles, one being used as digester and another one as water bottle for collecting biogas, a set of beakers for collecting water, connection piping components, and water bath vessel for maintaining the temperature. Each digester covered with a cap contained two circular holes, one of which acted as an opening to withdraw sludge sample to analyze the process parameters during anaerobic digestion while the second hole was connected with the water bottle through a pipe having port for taking gas sample for GC analysis. The water bottle was filled in sodium hydrogen bicarbonate to prevent $\mathrm{CO}_{2}$ solubility in the water. The produced biogas 
TABLE 1: Bagasse and filter mud mixing ratio.

\begin{tabular}{lccc}
\hline ID & Filter mud & Bagasse & C/N ratio \\
\hline 1 & $0 \%$ & $100 \%$ & 29.646 \\
2 & $50 \%$ & $50 \%$ & 19.754 \\
3 & $25 \%$ & $75 \%$ & 24.700 \\
4 & $75 \%$ & $25 \%$ & 14.808 \\
5 & $100 \%$ & $0 \%$ & 9.862 \\
\hline
\end{tabular}

from each digester was captured in the water bottle and the displaced liquid was in turn collected in the set of beakers to measure the biogas volume by the water displacement technique. Biogas composition and total biogas production was measured on daily basis while $\mathrm{pH}, \mathrm{COD}$, and $\mathrm{NH}_{3}-\mathrm{N}$ were done every 3 days.

2.3.2. Substrate Composition. Five proportions of bagasse and filter mud (basis TS total solid) were selected as shown in Table 1.

The proportion of the bagasse and filter mud was diluted to $6 \%$ total solid concentrations. It was inoculated with the sludge collected from an anaerobic digestion plant for pig farm waste (Nanjing Kaiping Family Farm, Poukou, Nanjing, China) and sieved through 20-mesh filter screen. Chemical characteristics of the sludge were determined as total solids (TS) $(2.01 \pm 0.05) \%$; volatile solids (VS) $(47.90 \pm 0.7) \%$; $\mathrm{pH}$ value 7.76 ; soluble chemical oxygen demands (CODs) $1320 \mathrm{mg} / \mathrm{L}$; and ammonia nitrogen $\left(\mathrm{NH}_{3}-\mathrm{N}\right) 1197 \mathrm{mg} / \mathrm{L}$.

Inoculum sludge was adjusted to be $40 \%$ from the total solid of the substrate volume; the total substrate in the digester was 0.8 liter including the sludge. $\mathrm{pH}$ during anaerobic digestion process was controlled to be between 6.5 and 8.5 by injecting hydrochloric acid $(\mathrm{HCl})$ or sodium hydroxide $(\mathrm{NaOH})$ solution into the digester through sampling hole if it was below or above the range. All anaerobic digestion tests were carried out at $(37 \pm 1)^{\circ} \mathrm{C}$ for about 35 days.

2.4. Analytical Methods. Total solids (TS), volatile solids (VS), ashes, total organic carbon (TOC), total nitrogen (TN), total phosphorus (TP), total potassium (TK), and soluble chemical oxygen demand (CODs) were determined according to standard methods [36]. Lignocellulosic characteristics were determined according to the Van Soest method [37], with a fiber extractor (VELP Scientifica Company, Italy). It is based on sequential extraction under neutral and acid detergent (NDF, ADF), followed by strong acid extraction (ADL). Different fractions are (a) soluble in neutral detergent fraction (1-NDF); (b) hemicelluloses (NDF-ADF) which is extracted by acid detergent; (c) cellulose (ADF-ADL) which is extracted by $76 \%$ sulphuric acid; and (d) lignin (ADL). pH was monitored in samples using digital pH meter (FE20K, Mettler-Toledo, Switzerland) capable of measuring in liquid substrates. Samples for analysis CODs and ammonia nitrogen $\left(\mathrm{NH}_{3}-\mathrm{N}\right)$ were centrifuged at $10,000 \mathrm{rpm}$ for $4 \mathrm{~min}$ in a centrifuge. After centrifugation, only the supernatant was used. Ammonia nitrogen $\left(\mathrm{NH}_{3}-\mathrm{N}\right)$ was determined from filtered samples, which diluted with deionized water in a proportion
TABLE 2: Characteristics of filter mud and bagasse samples.

\begin{tabular}{lccc}
\hline Parameters & Unit & Bagasse & Press mud \\
\hline Total solids (TS) & $(\%)$ & $58.900 \pm 0.001$ & $47.850 \pm 0.002$ \\
Volatile matter (VS) & $(\%)$ & $97.590 \pm 0.003$ & $34.780 \pm 0.013$ \\
Organic matter & $(\%)$ & $94.910 \pm 3.086$ & $28.150 \pm 0.326$ \\
TOC & $(\%)$ & $55.050 \pm 1.789$ & $16.330 \pm 0.783$ \\
Total-N & $(\%)$ & $1.857 \pm 0.419$ & $1.686 \pm 0.325$ \\
Total-P & $(\%)$ & $0.345 \pm 0.052$ & nd $^{*}$ \\
Total-K & $(\%)$ & $2.100 \pm 0.141$ & nd \\
C/N ratio & & 29.646 & 9.682 \\
\hline
\end{tabular}

Note: each value represents mean \pm STDEV of two replications. $\mathrm{nd}^{*}=$ not detected.

of $1: 200$ using a bench top spectrophotometer (Lianhua Co., Shanghai).

The biogas composition $\left(\mathrm{CH}_{4}\right.$ and $\left.\mathrm{CO}_{2}\right)$ measurement was conducted through biogas sampling from reactors by a special syringe and injection to the thermal conductivity detector (TCD) of gas chromatograph (Agilent 7820A) equipped with PQ 80-100 mesh column. The operation condition was as follows: $25 \mathrm{~mL} / \mathrm{min}$ helium as the carrier gas and detector temperature $250^{\circ} \mathrm{C}$ and $90^{\circ} \mathrm{C}$ of column temperature.

2.5. Statistical Analyses. Two-way ANOVA (Analysis of Variance) was used to test significant differences in mean values between treated and untreated samples for lignocelluloses properties and methane production. Furthermore, the graphical representation of the data was provided by using Analytical Software Package (Graph Pad, Prism 6.01).

\section{Results and Discussion}

3.1. Characteristics and Composition. General characteristics of fresh sugarcane bagasse and filter mud used during batch experiments are presented in Table 2. The total solid in the samples varied from $58.9 \%$ for bagasse and $47.85 \%$ for the filter mud. Filter mud and bagasse were close in nitrogen content, while bagasse contained a considerable amount of organic carbon and organic matter concentrations.

Filter mud had greater amount of ash. The carbon to nitrogen ratio $(\mathrm{C} / \mathrm{N})$ needed for effective digestion is between 10 and 30 [38]. The $\mathrm{C} / \mathrm{N}$ ratio of filter-cake is approximately 9.6 but for bagasse it is approximately 29.6. This composition mainly for bagasse is in good agreement with that reported in previous studies $[6,15]$.

\subsection{Effect of Sodium Hydroxide Pretreatments on Sugarcane} Bagasse Composition. The main advantages of the alkali pretreatment are removal of lignin and increasing the availability of cellulose for the bacterial metabolism during the anaerobic digestion process [39]. Lignin removal is an important part of the pretreatment process, because lignin can effectively inhibit/prevent the cellulase enzymes from hydrolyzing the cellulose. Alkaline pretreatment by adding $\mathrm{NaOH}$ solution 
TABLE 3: Percentage of chemical compounds of sugarcane bagasse.

\begin{tabular}{lcccc}
\hline Treatment & Autoclaving time (minutes) & Hemicellulose (\%) & Cellulose (\%) & Lignin (\%) \\
\hline Untreated & 0 & $32.293 \pm 0.491$ & $35.612 \pm 2.775$ & $22.563 \pm 2.933$ \\
$\mathrm{NaOH} 1 \mathrm{~N}$ & 15 & $11.258 \pm 0.459$ & $42.657 \pm 1.851$ & $4.514 \pm 1.567$ \\
$\mathrm{NaOH} 1 \mathrm{~N}$ & 30 & $8.732 \pm 0.077$ & $40.062 \pm 0.029$ & $4.715 \pm 1.877$ \\
$\mathrm{NaOH} 1 \mathrm{~N}$ & 45 & $11.083 \pm 0.915$ & $58.548 \pm 0.014$ & $3.096 \pm 0.366$ \\
\hline
\end{tabular}

causes a swelling of the biomass, which increases the internal surface area of the lignocellulose particles, as well as weakening the structural integrity of the lignocellulose and breaking bond linkages between lignin and the other carbohydrates (cellulose and hemicellulose), resulting in greater accessibility and digestibility of the cellulose fraction, and it can be depolymerized into fermentable sugars [26]. In order to determine the efficiency of different biomass plants degradation hemicellulose, cellulose and lignin content in the pretreated bagasse were measured and illustrated in Table 3.

As shown in Table 3, untreated bagasse contained 35.61\% of cellulose and $22.56 \%$ of lignin, after being autoclaved at $100^{\circ} \mathrm{C}$ by $\mathrm{NaOH} 1 \mathrm{~N}$ for 15 minutes of delignification. The cellulose increased by $16.5 \%$ and lignin decreased by $80 \%$. Meanwhile, for 30 minutes of delignification, cellulose shifted to $40.06 \%$ or increased $11 \%$ and lignin content shifted to $4.72 \%$ or decreased $79 \%$. Moreover, after delignification by $\mathrm{NaOH} 1 \mathrm{~N}$ for 45 minutes, cellulose increased by $39.1 \%$ and lignin content decreased by $86.2 \%$. From this data, it could be observed that the cellulose content increased more and lignin content decreased by increasing the delignification time. The significant increase of cellulose content was probably because cellulose in solid phase is high and only slight fraction of lignin is extracted in the liquid phase. After pretreatment, the cellulose could be still in solid phase and small fraction will be in liquid phase. This is in agreement with the findings of Maryana et al., who evaluate the effect of alkaline pretreatment on the chemical composition and structure of sugarcane bagasse by using 1 and $2 \mathrm{~N} \mathrm{NaOH}$ concentration and 4 periods of delignification and found that there was about $59.1 \%$ and $42.3 \%$ lignin loss after 1 and $2 \mathrm{~N}$ alkaline pretreatment in 30 and 40 minutes of delignification, respectively [34]. Wang et al. reported that the loss of hemicellulose and lignin of rice straw was $89.45 \%$ and $88.92 \%$, respectively, at $4.0 \%$ $\mathrm{NaOH}$ [40]. Effect of different alkaline dosages (4\% and 10\% $\mathrm{gNaOH} / \mathrm{gTS})$, temperatures $\left(40^{\circ} \mathrm{C}\right.$ and $\left.55^{\circ} \mathrm{C}\right)$, and contact times ( $12 \mathrm{~h}$ and $24 \mathrm{~h}$ ) in structural feature of sorghum forage was investigated and it was found that, by increasing the $\mathrm{NaOH}$ dosage, a reduction of hemicelluloses (from $37 \%$ to $70 \%$ ) and lignin contents (from $26 \%$ to $70 \%$ ) was observed [41]. Therefore, it can be concluded that delignification by $\mathrm{NaOH} 1 \mathrm{~N}$ for 45 minutes was the most effective for delignification process because the decreasing rate of lignin level was the highest. Comparison of the level of lignin, hemicellulose, and cellulose content after being treated by $\mathrm{NaOH} 1 \mathrm{~N}$ is illustrated in Figure 1. It is shown that the lignin content after cooking for 45 minutes was the lowest, 3.096\%. In addition, percentages of the lignin content after cooking times of 30 minutes and 15 minutes and untreated bagasse were $4.715,4.514$, and $22.563 \%$, respectively.

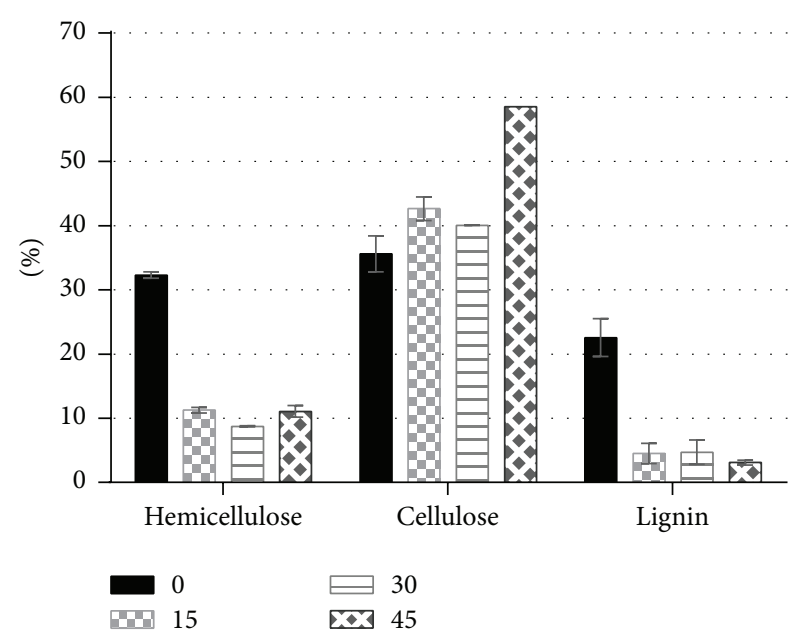

FIGURE 1: Comparison of chemical composition in bagasse after delignification by $\mathrm{NaOH} 1 \mathrm{~N}$.

3.3. Daily Biomethane Production. In general, the daily biomethane production has been summarized in Figures 2(a)-2(e); all groups had two methane production periods. Obviously, there were higher peaks of methane production in the first 6 days, which could be mainly caused by degradation of soluble sugar in the substrate. In the second period, methane production rate decreased and goes in stability for about 10 days with the decomposition of cellulose and hemicelluloses. Furthermore, biogas production decreased slowly in the last 10 days.

3.3.1. Codigestion of Filter Mud with Bagasse in C/N Ratio. Filter mud was codigested with bagasse at mesophilic temperatures $\left(37^{\circ} \mathrm{C}\right)$ using five different combinations in order to determine the effect of codigestion on biogas and methane production. The $\mathrm{C} / \mathrm{N}$ ratio of filter mud was 9.6 , which is lower than the optimum required for biomethanation [42]. To increase the $\mathrm{C} / \mathrm{N}$ ratio, filter mud was mixed with bagasse in different proportions as in Table 1 . The overall maximum biomethane yield was $22.2 \mathrm{~mL} \cdot \mathrm{gVS}^{-1}(72.5 \%$ more than the digestion of pure filter mud) and was achieved in codigestion ratio of $25 \%$ filter mud and $75 \%$ bagasse with $\mathrm{C} / \mathrm{N}$ ration 24.7 which is $60 \%$ greater than $\mathrm{C} / \mathrm{N}$ ratio of pure filter mud. The lowest yield was obtained with filter mud as the only substrate $(\mathrm{C} / \mathrm{N}$ ratio of 9.862$)$. These results confirm that microorganism's metabolic activity is significantly influenced by the nutrient ratio [43], maximum yield occurred around a $\mathrm{C} / \mathrm{N}$ ratio of $25 \mathrm{~g} \mathrm{C} / \mathrm{g} \mathrm{N}$, and this occurs because microorganisms utilize carbon 25 times faster than nitrogen. However, 


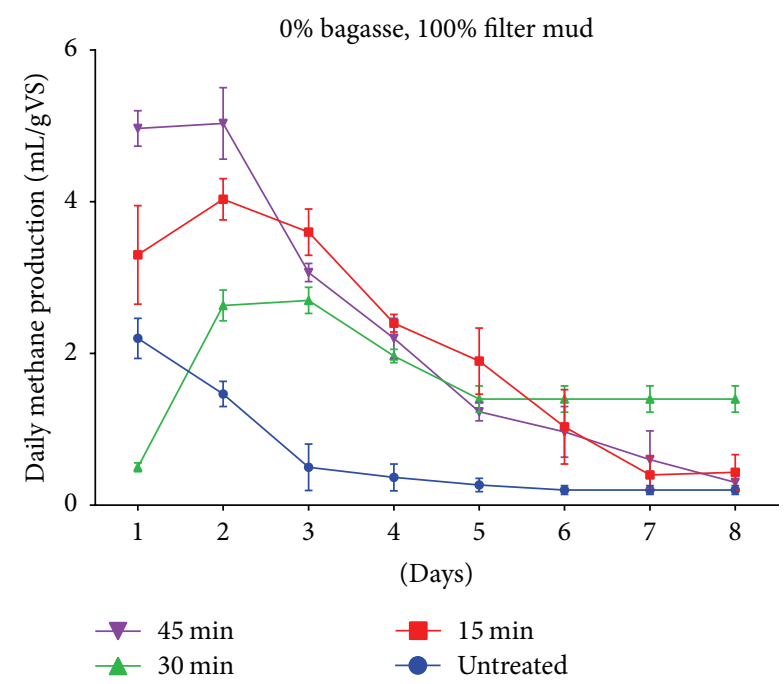

(a)

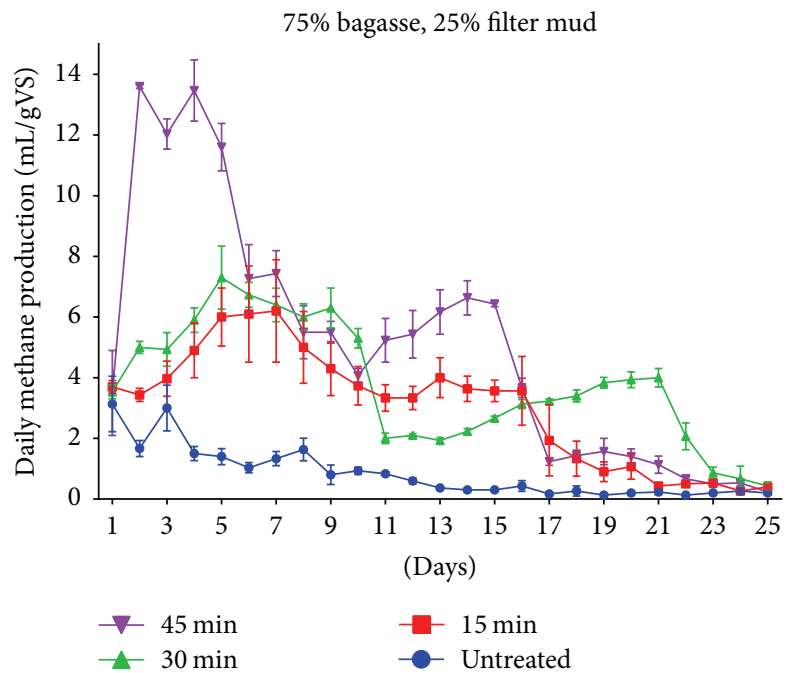

(c)

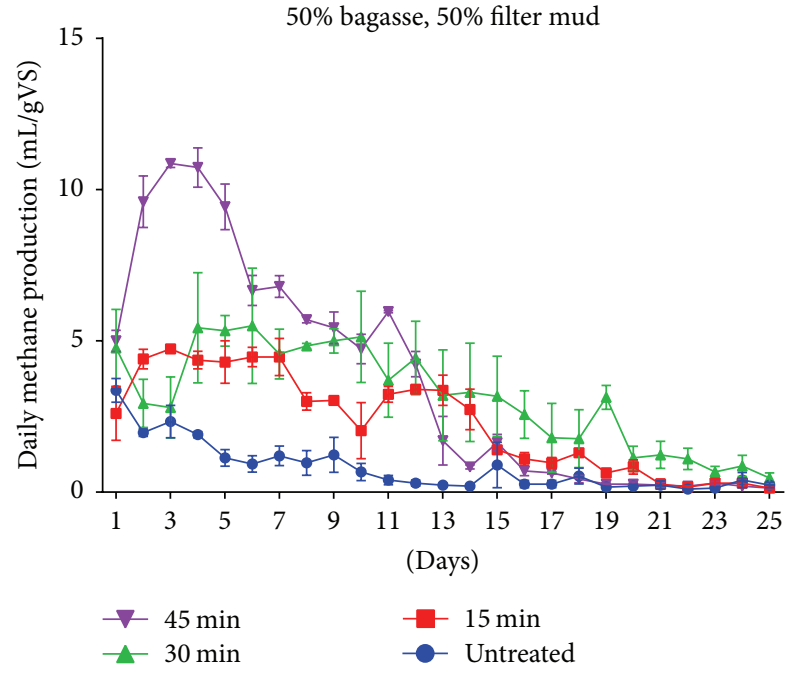

(b)

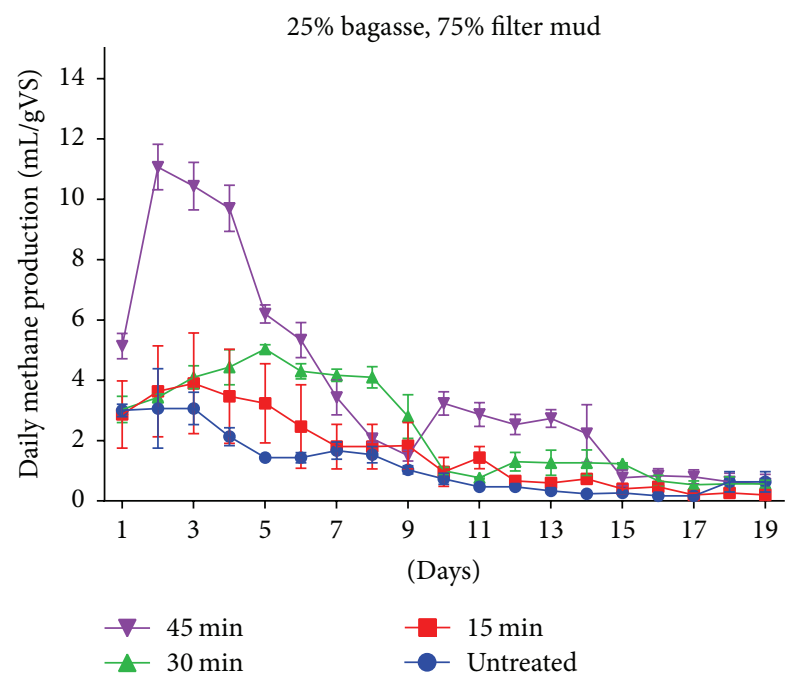

(d)

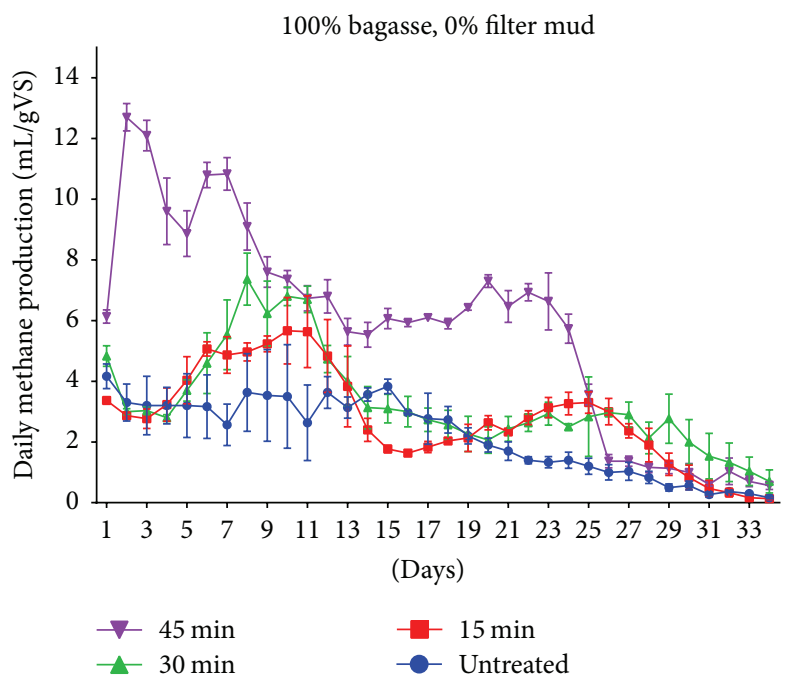

(e)

FIGURE 2: Daily methane production by different codigestion rates and pretreatments time. 
TABLE 4: Cumulative biomethane yields (in $\mathrm{mL} \mathrm{gVS}^{-1}$ ) at different pretreatment periods and codigestion ratios.

\begin{tabular}{|c|c|c|c|c|}
\hline Codigestion ratios & & Pretre & & \\
\hline Filter mud, bagasse & 0 min (untreated) & $15 \mathrm{~min}$ & $30 \mathrm{~min}$ & $45 \mathrm{~min}$ \\
\hline $0 \%, 100 \%$ & 76.0 & 97 & 113.0 & 195.8 \\
\hline $50 \%, 50 \%$ & 21.1 & 58.2 & 80.4 & 92.8 \\
\hline $25 \%, 75 \%$ & 23.7 & 79.9 & 96.4 & 126.2 \\
\hline $75 \%, 25 \%$ & 22.2 & 32.1 & 44.5 & 72.1 \\
\hline $100 \%, 0 \%$ & 6.1 & 17.5 & 9.2 & 18.3 \\
\hline
\end{tabular}

the optimum $\mathrm{C} / \mathrm{N}$ ratios have been reported in literature. For anaerobic digestion of filter mud, $\mathrm{C} / \mathrm{N}$ ratio of 18 was found to be optimum for biogasification of filter mud [15]. For methane formation from agroindustrial waste such as molasses, Iqbal et al. found that $\mathrm{C} / \mathrm{N}$ ratio of 30 , based on organic carbon and total nitrogen, is optimal [44].

The results demonstrate that codigestion of bagasse with filter mud produces less biogas than digestion of bagasse alone (76.0 and $6.1 \mathrm{~mL} \cdot \mathrm{gVS}^{-1}$ for pure bagasse and filter mud, resp.). It can be explained by the high ash content found in filter mud due to its characteristics which depend on cane variety, soil condition, and other environmental factors. This sample of filter mud was collected from Land-Reclamation Sugar Industry Company.

3.3.2. Effect of Alkaline Pretreatment on Methane Yield. The methane yield is defined as $\mathrm{CH}_{4}$ production per unit volatile solids (in $\mathrm{mL} \mathrm{CH}_{4} / \mathrm{g} \mathrm{VS}$ ); different pretreatment time was tested in order to study the effect of $\mathrm{NaOH}-1 \mathrm{~N}$ on enhancing the biomethane production of hydrolyses and degradation of lignocellulose. As shown in Figures 2(a)-2(e) and Table 4, the filter mud and bagasse pretreated by alkaline had significantly increased their cumulative biomethane yields in all codigestion ratios $(P<0.0001)$ compared with untreated ones, by increasing the cooking time of the substrate with $\mathrm{NaOH}$. The highest cumulative biomethane production achieved in this study was $195.8 \mathrm{~mL} \mathrm{gVS}^{-1}$ in digestion of pure bagasse treated for $45 \mathrm{~min}$, which was $61.2 \%$ higher than untreated bagasse. However, an improvement of $66.6 \%$ was achieved in digestion of pure filter mud treated in the same cooking period $\left(18.3 \mathrm{~mL} \mathrm{gVS}^{-1}\right)$ compared with untreated filter mud $\left(6.1 \mathrm{~mL} \mathrm{gVS}^{-1}\right)$. These findings are consistent with previous studies $[18,45,46]$ which verified the effectiveness of $\mathrm{NaOH}$ pretreatment in improving biodegradability and enhancing biomethane production. The cumulative biomethane yield was $92.8 \mathrm{~mL} \mathrm{gVS}^{-1}$ when filter mud and bagasse were mixed in 50:50 ratio. The yield was decreased to $72.1 \mathrm{~mL} \mathrm{gVS}^{-1}$ when filter mud content was increased to a mixture of $75: 25$ ratio. However, in all mixtures, the cumulative gas yield was lower as compared to that of bagasse alone, as the filter mud ratio increased in codigestion, the biomethane decreased drastically. Furthermore, the cumulative biomethane yield reached $126.2 \mathrm{mLgVS}^{-1}$ when filter mud codigested with bagasse in $25: 75$ ratio increased by $81.20 \%$ from untreated composition.
3.4. Effect of $p H$. Initially the $\mathrm{pH}$ of the substrate was found to be higher than 10 due to alkaline pretreatment. It was adjusted one time before starting fermentation in the range of 6.9-8.1 by the addition of hydrochloric acid $(\mathrm{HCl})$; these values are in agreement with the operational range of 6.5-8.5 reported previously for an anaerobic digestion process [38]. The variation in $\mathrm{pH}$ over the period of digestion was within the range as shown in Figure 3(b). There was an initial decrease in $\mathrm{pH}$ values after two days of digestion as the concentration of acids increased, due to an imbalance between production and consumption of acids by methanogenic bacteria [47].

3.5. Effect of Pretreatment on CODs Concentration and COD Removal. Soluble chemical oxygen demand (COD) is considered the most important parameter for the anaerobic digestion process; the CODs were examined in three-day intervals during the anaerobic digestion process; $\mathrm{NaOH}$ pretreatment showed significant increase in the CODs concentration in all levels of codigestion, as shown in Figure 3(a). CODs values obtained after pretreatment were ranged from 1,312 to $20,384 \mathrm{mg} / \mathrm{L}$ in comparison with 320 to $3,912 \mathrm{mg} / \mathrm{L}$ for the untreated ones. At the beginning of the fermentation process, due to intense mineralization of the reactants, a considerable decrease in COD occurred. By the end, when microorganisms do not exhibit a living behavior and the process stopped, the CODs decreased; these results are in accordance with the previous research [44]. For untreated substrate, the CODs concentration increased rapidly when the percentage of bagasse increased in codigestion, which was 3,$912 ; 3,065 ; 3,200 ; 2,480$; and 2,416 mg/L for pure bagasse, $50 \%$ bagasse $50 \%$ filter mud, $75 \%$ bagasse $25 \%$ filter mud, $25 \%$ bagasse $75 \%$ filter mud, and pure filter mud, respectively. The maximum CODs value for treated bagasse and filter mud was obtained when bagasse and filter mud were treated for 30 min with $\mathrm{NaOH}, 20,384 ; 13,424 ; 16,448 ; 9,872$, and $6,248 \mathrm{mg} / \mathrm{L}$, respectively, with the same sequence mentioned above for untreated substrate. Moreover, CODs by $45 \mathrm{~min}$ of cooking were higher than $15 \mathrm{~min}$. The highest COD solubilization reached in the current work was $20,384 \mathrm{mg} / \mathrm{L}$ obtained for reactor with pure bagasse pretreated with $\mathrm{NaOH}$ for $30 \mathrm{~min}$, resulting in an increase of $80.8 \%$ with respect to untreated reactor with the same composition 3,912 mg/L. Meanwhile, the maximum CODs for reactor with pure filter mud pretreated with $\mathrm{NaOH}$ for $30 \mathrm{~min}$ were $6,248 \mathrm{mg} / \mathrm{L}$, by increasing $60.3 \%$ with respect to untreated reactor with the same composition $2,480 \mathrm{mg} / \mathrm{L}$. A possible reason for 


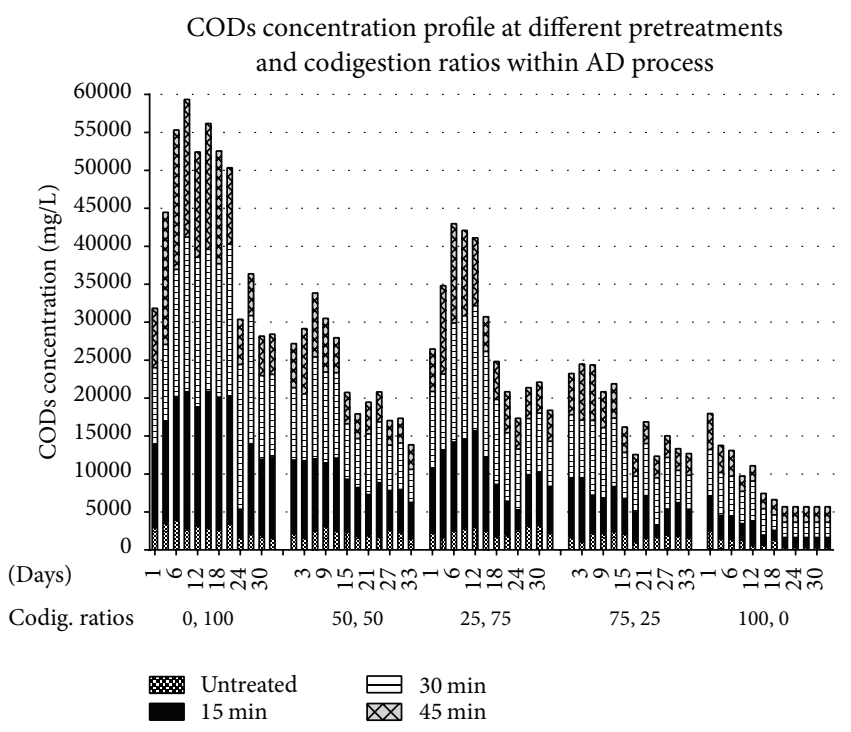

(a)

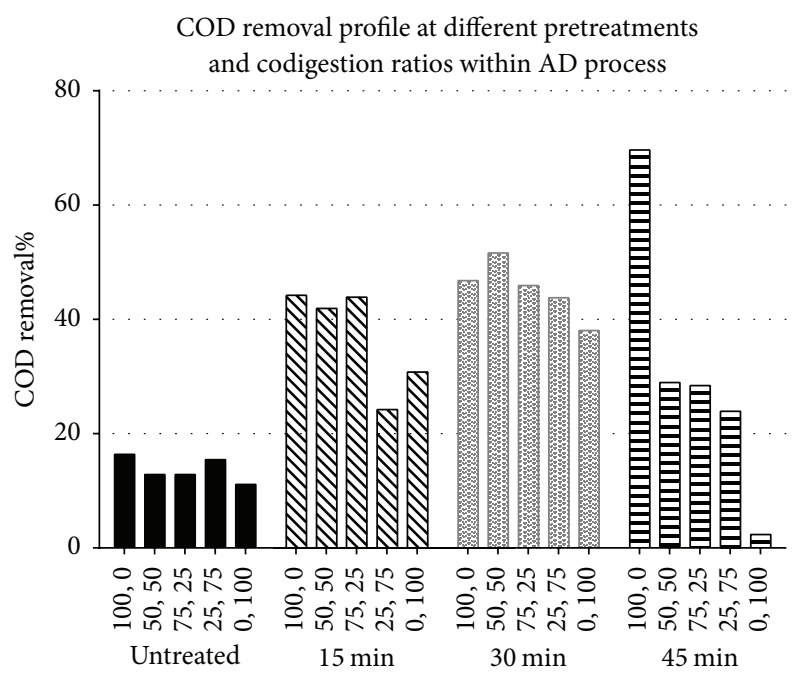

(c)

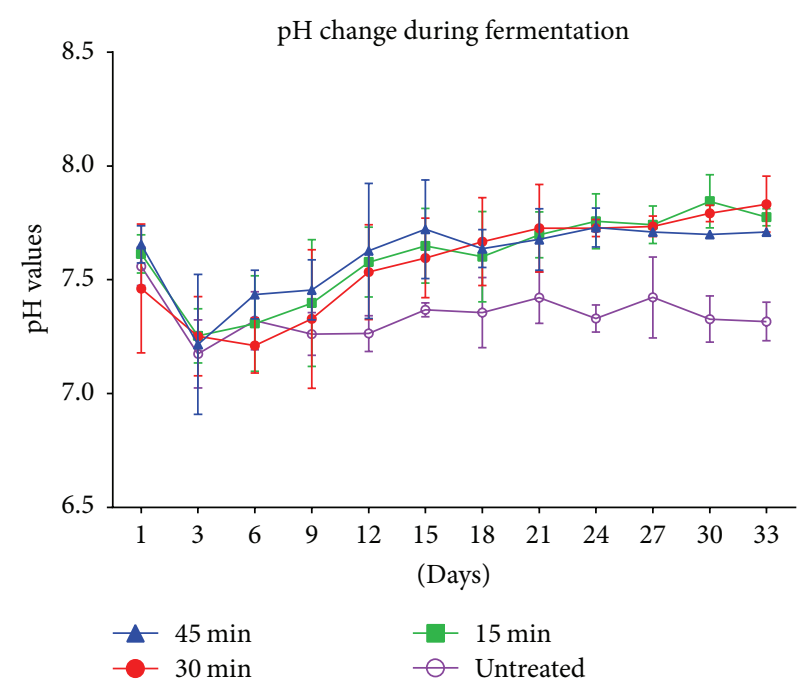

(b)

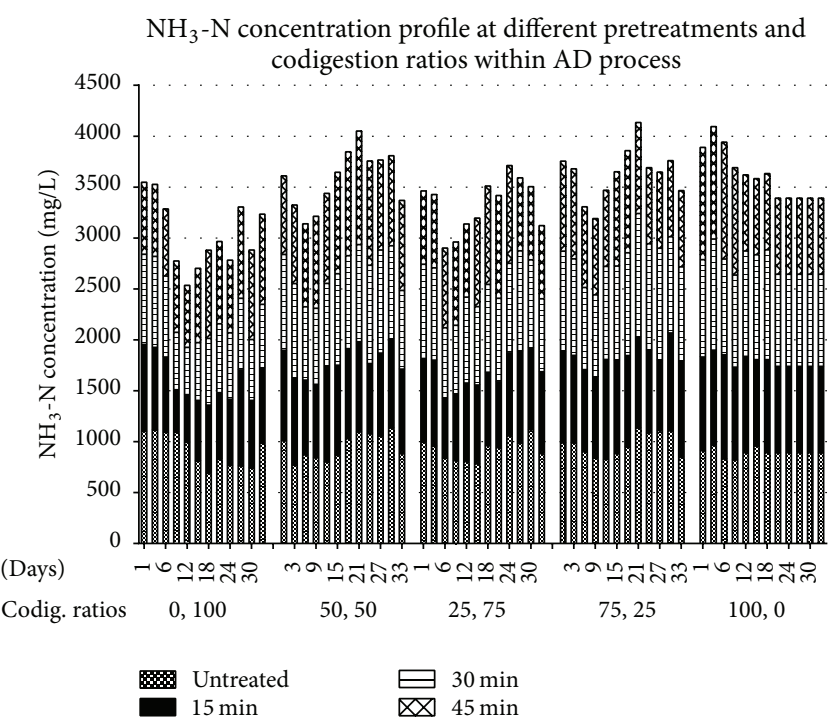

(d)

FIGURE 3: Basic anaerobic digestion process profiles.

these higher CODs values is the alkaline pretreatment which causes hemicelluloses and parts of lignin to solubilize and subsequently higher organic degradation [40]. These results proved that pretreatment was more efficient with respect to promoting hydrolysis and increasing COD concentration. The highest COD solubilizations were achieved in the thermoalkaline pretreatments of sorghum forage and wheat straw, at 40 and $100^{\circ} \mathrm{C}$ with $10 \% \mathrm{NaOH}$ for both substrates (around $30-40 \%$ for both substrates) [18]. González et al. evaluated different pretreatment time and lime loading on filter mud and reported that the highest COD solubilization was obtained when $3.18 \mathrm{~g} / \mathrm{L}$ of $\mathrm{Ca}(\mathrm{OH})_{2}$ with $7.33 \mathrm{~h}$ of pretreatment time gives $6 \%$ over untreated press mud [12].

COD removal fluctuated in the initial startup stage of fermentation and stabilized after one week of operation. COD reduction was between 69.64 and $4 \%$ during the entire period of the study as shown in Figure 3(c). As could be shown, the percentage of COD removal values of the pretreated samples was significantly higher than the untreated sample. However, the highest methane yield $\left(195.8 \mathrm{~mL} \mathrm{gVS}^{-1}\right)$ was observed in pretreated samples with the highest COD removal (69.64\%).

3.6. Ammonia Nitrogen Concentration $\left(\mathrm{NH}_{3}-\mathrm{N}\right)$. Nitrogen supplementation in the form of organic nitrogen or ammonia nitrogen is an essential nutrient for anaerobic digestion. It may inhibit microbial activities during anaerobic digestion process if it is available at high concentrations [48]. Inhibition of the anaerobic digestion process is usually indicated by the decrease in the steady state methane production rates and the increase in the intermediate digestion products like acids concentrations [49]. Such an unstable state may happen as a 
result of total ammonia nitrogen levels up to a range of $1500-$ $7000 \mathrm{mg} / \mathrm{L}$ [50]. Currently, there are no reports about ammonia inhibitory effects on anaerobic digestion of lignocelluloses biomass with nitrogen supplementation. Wang et al. [51] have experimentally investigated the effect of total ammonia nitrogen on solid-state anaerobic digestion of corn stover. They found that concentrations higher than $2.5 \mathrm{~g} / \mathrm{kg}$ (based on total weight) caused a significant reduction of methane yields by $50 \%$. In this study, the concentration of $\mathrm{NH}_{3}-\mathrm{N}$ in all codigestion ratios and pretreatment levels was lower than level of inhibition as shown in Figure 3(d). Whereas for untreated substrate, the $\mathrm{NH}_{3}-\mathrm{N}$ concentration between 822 and $1,114 \mathrm{mg} / \mathrm{L}$, pretreatment resulted in a decrease in the $\mathrm{NH}_{3}-\mathrm{N}$ concentration from 608.8 to $1,058 \mathrm{mg} / \mathrm{L}$ in the reaction with pure bagasse treated for $45 \mathrm{~min}$.

\section{Conclusions}

The biomethane production from codigestion of filter mud and sugarcane bagasse with and without $\mathrm{NaOH}$ pretreatment was determined using anaerobic batch digesters. Lower $\mathrm{C} / \mathrm{N}$ ratio (9.862) is the main problem of press mud for biomethanation. Mixing of other substrates of high $\mathrm{C} / \mathrm{N}$ ratio like bagasse (26.646) resulted in optimum $\mathrm{C} / \mathrm{N}$ ratio. Pretreatment by cooking the substrates at $100^{\circ} \mathrm{C}$ with $\mathrm{NaOH}$ $1 \mathrm{~N}$ for 45 minutes has a higher cumulative biomethane yield in all levels of codigestion compared to other pretreatment times and to untreated groups. Mixing of filter mud in the ratio of $25: 75$ ( $\mathrm{C} / \mathrm{N}$ ration 24.70$)$ provided the best cumulative biomethane for untreated substrates and $126.2 \mathrm{~mL} \mathrm{gVS}^{-1}$ with an increase of $81.20 \%$ from untreated composition for pretreated substrates. Furthermore, cellulose level increased after pretreatment which is in consistency with the decreasing level of lignin; the lignin content after cooking for 45 minutes was the lowest $(3.096 \%)$. The results showed that codigestion with bagasse could be considered as an efficient method to improve biogas production from filter mud.

\section{Competing Interests}

The authors declare that there is no conflict of interests regarding the publication of this paper.

\section{Acknowledgments}

The authors are thankful to the National Science and Technology Support Program (2013BAD08B04) for financial support; the Institute of Agricultural Resources and Environment, Jiangsu Academy of Agricultural Science, for some technical support; and Dr. Yonglan Xi for her constructive comments.

\section{References}

[1] M. A. Karan, B. R. Barve, and S. S. Khan, "Biogas from press mud," IOSR Journal of Mechanical and Civil Engineering, vol. 46, no. 2, pp. 37-41, 2012.

[2] A. E. Cioablă and I. Ionel, "Biomass waste as a renewable source of biogas production-experiments," in Alternative Fuel, InTech, 2011.
[3] M. C. Ruppert, The Decline of the American Empire at the End of the Age of Oil, 2004.

[4] T. D. Yavini, U. H. Taura, N. Mohammed, and J. M. Namo, "Comparative study of mesophilic biogas production potentials of selected agro-wastes," The International Journal of Engineering and Science, vol. 3, no. 2, pp. 1-6, 2014.

[5] Z. Anwar, M. Gulfraz, and M. Irshad, "Agro-industrial lignocellulosic biomass a key to unlock the future bio-energy: a brief review," Journal of Radiation Research and Applied Sciences, vol. 7, no. 2, pp. 163-173, 2014.

[6] C. A. Rezende, M. De Lima, P. Maziero, E. Deazevedo, W. Garcia, and I. Polikarpov, "Chemical and morphological characterization of sugarcane bagasse submitted to a delignification process for enhanced enzymatic digestibility," Biotechnology for Biofuels, vol. 4, article 54, 2011.

[7] I. M. Ime, "Biochar from anaerobically digested sugarcane bagasse," in Graduate School, University of Florida, 2010.

[8] A. Pandey, C. R. S. Soccol, P. Nigam, and V. T. Soccol, "Biotechnological potential of agro-industrial residues. I: sugarcane bagasse," Bioresource Technology, vol. 74, no. 1, pp. 69-80, 2000.

[9] B. E. L. Baêta, D. R. S. Lima, O. F. H. Adarme, L. V. A. Gurgel, and S. F. D. Aquino, "Optimization of sugarcane bagasse autohydrolysis for methane production from hemicellulose hydrolyzates in a biorefinery concept," Bioresource Technology, vol. 200, pp. 137146, 2016.

[10] H. Li, K. Sheng, X. Chen, R. Kloss, and T. Scilley, "A comparison of liquid hot water and $\mathrm{NaOH}$ pretreatment on anaerobic digestion of sugar cane bagasse for biogas production," in Proceedings of the American Society of Agricultural and Biological Engineers Annual International Meeting, pp. 4216-4221, Kansas, Miss, USA, July 2013.

[11] B. Sengupta, P. K. Mahendru, S. Kumar, A. Sagar, S. C. Sharma, and K. S. Krishnan Marg, Bio-Methanation Potential of Solid Wastes from Agro-Based Industries, Central Pollution Control Board Ministry of Environment \& Forests, New Delhi, India, 2007.

[12] L. M. L. González, H. Vervaeren, I. P. Reyes, A. Dumoulin, O. R. Romero, and J. Dewulf, "Thermo-chemical pre-treatment to solubilize and improve anaerobic biodegradability of press mud," Bioresource Technology, vol. 131, pp. 250-257, 2013.

[13] N. Gupta, S. Tripathi, and C. Balomajumder, "Characterization of pressmud: a sugar industry waste," Fuel, vol. 90, no. 1, pp. 389394, 2011.

[14] M. Dietrich, Project Opportunity Fact Sheet Biogas Potential from Filter Mud, Project Development Programme (PDP), D.G.f.I.Z. (GIZ), 2014.

[15] M. A. Rouf, P. K. Bajpai, and C. K. Jotshi, "Optimization of biogas generation from press mud in batch reactor," Bangladesh Journal of Scientific and Industrial Research, vol. 45, no. 4, pp. 371-376, 2011.

[16] B. Radjaram, R. Saravanane, and T. Sundararajan, "Feasibility study of biohydrogen production from pressmud by UASB process and assessment of operating parameters," Global Nest Journal, vol. 15, no. 4, pp. 560-567, 2013.

[17] A. G. Nufiez and M. S. Leal Silva, A Study on the Production of Biogas from Filter Press Mud, Cuban Sugar Research Institute, La Habana, Cuba, 1983.

[18] C. Sambusiti, F. Monlau, E. Ficara, H. Carrère, and F. Malpei, "A comparison of different pre-treatments to increase methane production from two agricultural substrates," Applied Energy, vol. 104, pp. 62-70, 2013. 
[19] L. M. L. González, I. P. Reyes, J. Dewulf, J. Budde, M. Heiermann, and H. Vervaeren, "Effect of liquid hot water pretreatment on sugarcane press mud methane yield," Bioresource Technology, vol. 169, pp. 284-290, 2014.

[20] L. Janke, A. Leite, M. Nikolausz, and W. Stinner, Biogas Production from Sugarcane Filter Cake Start Up, 2015, http://www.waste-to-resources.eu.

[21] Y. X. Liu, J. Zhang, Y. Yuan et al., "Sequential bioethanol and biogas production from sugarcane bagasse based on high solids fed-batch SSF," Energy, vol. 90, article 7, 2015.

[22] X. Zhao, F. Peng, K. Cheng, and D. Liu, "Enhancement of the enzymatic digestibility of sugarcane bagasse by alkali-peracetic acid pretreatment," Enzyme and Microbial Technology, vol. 44, no. 1, pp. 17-23, 2009.

[23] L. Janke, A. F. Leite, M. Nikolausz, C. M. Radetski, M. Nelles, and W. Stinner, "Comparison of start-up strategies and process performance during semi-continuous anaerobic digestion of sugarcane filter cake co-digested with bagasse," Waste Management, vol. 48, pp. 199-208, 2016.

[24] Y. Zheng, J. Zhao, F. Xu, and Y. Li, "Pretreatment of lignocellulosic biomass for enhanced biogas production," Progress in Energy and Combustion Science, vol. 42, no. 1, pp. 35-53, 2014.

[25] J. S. Kim, Y. Y. Lee, and T. H. Kim, "A review on alkaline pretreatment technology for bioconversion of lignocellulosic biomass," Bioresource Technology, vol. 199, pp. 42-48, 2016.

[26] A. A. Modenbach and S. Nokes, "Effects of sodium hydroxide pretreatment on structural components of biomass," American Society of Agricultural and Biological Engineers (ASABE), vol. 57, no. 4, pp. 1187-1198, 2014.

[27] D. Yang, Y. Zheng, and R. Zhang, "Alkali pretreatment of rice straw for increasing the biodegradability," in Proceedings of the American Society of Agricultural and Biological Engineers Annual International Meeting, pp. 631-643, June 2009.

[28] S. Zhu, Y. Wu, Z. Yu, J. Liao, and Y. Zhang, "Pretreatment by microwave/alkali of rice straw and its enzymic hydrolysis," Process Biochemistry, vol. 40, no. 9, pp. 3082-3086, 2005.

[29] A. Singh, S. Tuteja, N. Singh, and N. R. Bishnoi, "Enhanced saccharification of rice straw and hull by microwave-alkali pretreatment and lignocellulolytic enzyme production," Bioresource Technology, vol. 102, no. 2, pp. 1773-1782, 2011.

[30] M. Hassan, W. Ding, J. Bi, E. Mehryar, Z. A. A. Talha, and $\mathrm{H}$. Huang, "Methane enhancement through oxidative cleavage and alkali solubilization pre-treatments for corn stover with anaerobic activated sludge," Bioresource Technology, vol. 200, pp. 405-412, 2016.

[31] A. Modenbach, Sodium hydroxide pretreatment of corn stover and subsequent enzymatic hydrolysis: an investigation of yields, kinetic modeling and glucose recovery [Theses and Dissertations], Biosystems and Agricultural Engineering, 2013.

[32] S. Bolado-Rodríguez, C. Toquero, J. Martín-Juárez, R. Travaini, and P. A. García-Encina, "Effect of thermal, acid, alkaline and alkaline-peroxide pretreatments on the biochemical methane potential and kinetics of the anaerobic digestion of wheat straw and sugarcane bagasse," Bioresource Technology, vol. 201, pp. 182-190, 2016.

[33] R. Velmurugan and K. Muthukumar, "Ultrasound-assisted alkaline pretreatment of sugarcane bagasse for fermentable sugar production: optimization through response surface methodology," Bioresource Technology, vol. 112, pp. 293-299, 2012.
[34] R. Maryana, D. Ma’rifatun, A. I. Wheni, K. W. Satriyo, and W. A. Rizal, "Alkaline pretreatment on sugarcane bagasse for bioethanol production," Energy Procedia, vol. 47, pp. 250-254, 2014.

[35] C.-H. Kuo and C.-K. Lee, "Enhanced enzymatic hydrolysis of sugarcane bagasse by $\mathrm{N}$-methylmorpholine- $\mathrm{N}$-oxide pretreatment," Bioresource Technology, vol. 100, no. 2, pp. 866-871, 2009.

[36] APHA, Standard Methods for the Examination of Water and Wastewater, American Public Health Association, American Water Works Association, Water Environment Federation, Washington, DC, USA, 1999.

[37] P. J. Van Soest and R. H. Wine, "Use of detergents in the analysis of fibrous feeds. IV. Determination of plant cellwall constituents," Journal-Association of Official Analytical Chemists, vol. 50, pp. 50-55, 1967.

[38] A. Teghammar, Biogas production from lignocelluloses: pretreatment, substrate characterization, co-digestion, and economic evaluation [Thesis for the Degree of Philosophy], Chalmers University of Technology, Göteborg, Sweden, 2013.

[39] K. Michalska, M. Bizukojć, and S. Ledakowicz, "Pretreatment of energy crops with sodium hydroxide and cellulolytic enzymes to increase biogas production," Biomass and Bioenergy, vol. 80, pp. 213-221, 2015.

[40] D. Wang, P. Ai, L. Yu, Z. Tan, and Y. Zhang, "Comparing the hydrolysis and biogas production performance of alkali and acid pretreatments of rice straw using two-stage anaerobic fermentation," Biosystems Engineering, vol. 132, pp. 47-55, 2015.

[41] C. Sambusiti, E. Ficara, F. Malpei, J. P. Steyer, and H. Carrère, "Influence of alkaline pre-treatment conditions on structural features and methane production from ensiled sorghum forage," Chemical Engineering Journal, vol. 211-212, pp. 488-492, 2012.

[42] A. D. Smith and M. T. Holtzapple, "Investigation of the optimal carbon-nitrogen ratio and carbohydrate-nutrient blend for mixed-acid batch fermentations," Bioresource Technology, vol. 102, no. 10, pp. 5976-5987, 2011.

[43] H. Rughoonundun, R. Mohee, and M. T. Holtzapple, "Influence of carbon-to-nitrogen ratio on the mixed-acid fermentation of wastewater sludge and pretreated bagasse," Bioresource Technology, vol. 112, pp. 91-97, 2012.

[44] K. Iqbal, T. Aftab, J. Iqbal, S. Aslam, and R. Ahmed, "Production of biogas from an Agro-industrial waste and its characteristics," Journal of Scientific Research, vol. 6, no. 2, 2014.

[45] R. Navia, M. Soto, G. Vidal, C. Bornhardt, and M. C. Diez, "Alkaline pretreatment of kraft mill sludge to improve its anaerobic digestion," Bulletin of Environmental Contamination and Toxicology, vol. 69, no. 6, pp. 869-876, 2002.

[46] M. Zheng, X. Li, L. Li, X. Yang, and Y. He, "Enhancing anaerobic biogasification of corn stover through wet state $\mathrm{NaOH}$ pretreatment," Bioresource Technology, vol. 100, no. 21, pp. 5140-5145, 2009.

[47] P. Horecky and M. Saska, Thermophilic Anaerobic Digestion of Filter Cake, Audubon Sugar Institute, Louisiana State University Agricultural Center, Baton Rouge, La, USA, 2004.

[48] O. Yenigün and B. Demirel, "Ammonia inhibition in anaerobic digestion: a review," Process Biochemistry, vol. 48, no. 5-6, pp. 901-911, 2013.

[49] R. Rajagopal, D. I. Massé, and G. Singh, "A critical review on inhibition of anaerobic digestion process by excess ammonia," Bioresource Technology, vol. 143, pp. 632-641, 2013. 
[50] J. P. Schwitzguébel, B. Dubois, A. Wellinger, and Y. Membrez, Anaerobic Digestion of Slaughterhouse By-Products and Catering Wastes, 2000.

[51] Z. Wang, F. Xu, and Y. Li, "Effects of total ammonia nitrogen concentration on solid-state anaerobic digestion of corn stover," Bioresource Technology, vol. 144, pp. 281-287, 2013. 

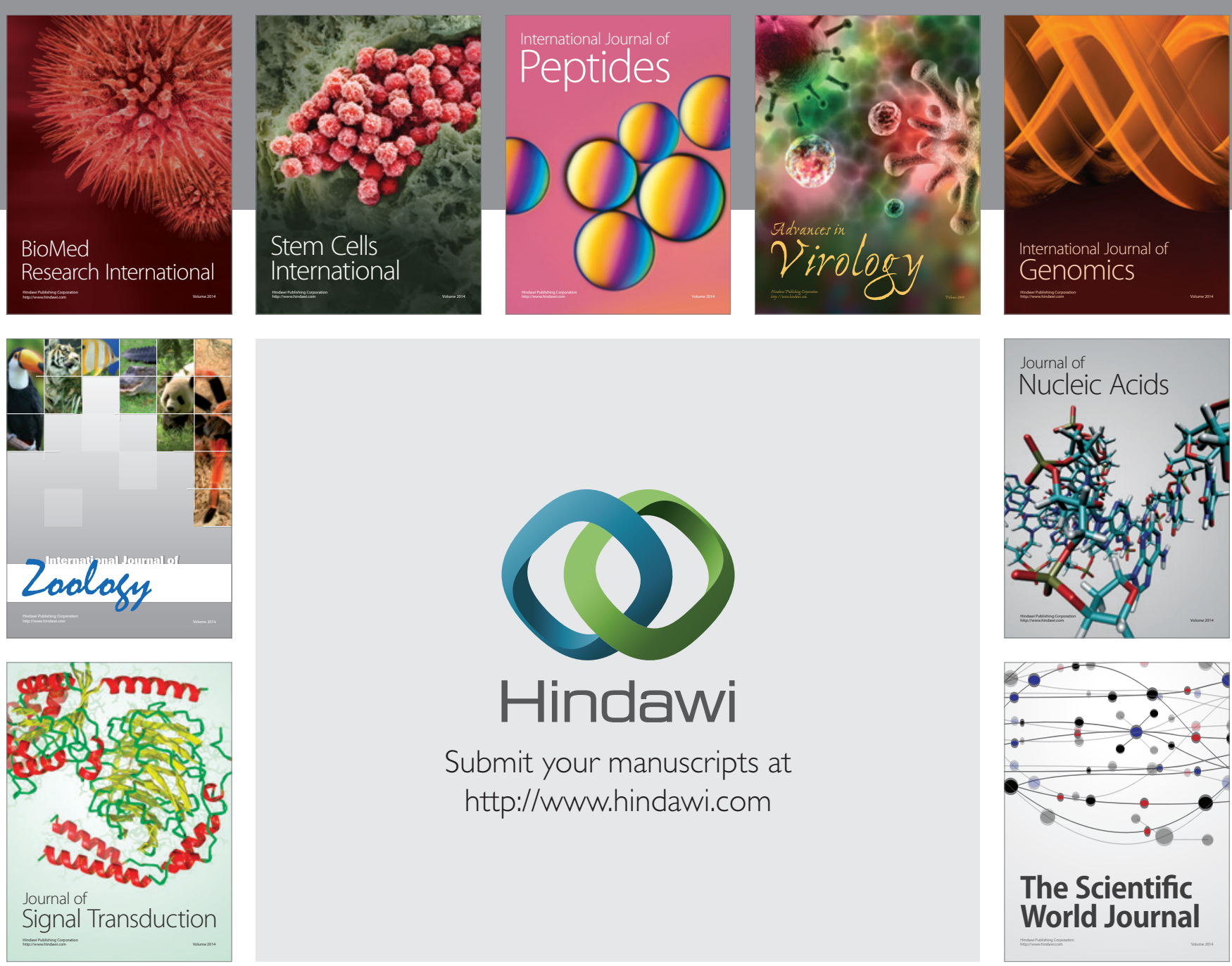

Submit your manuscripts at

http://www.hindawi.com
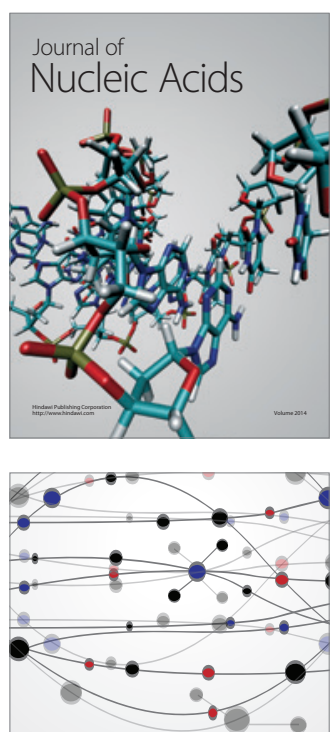

The Scientific World Journal
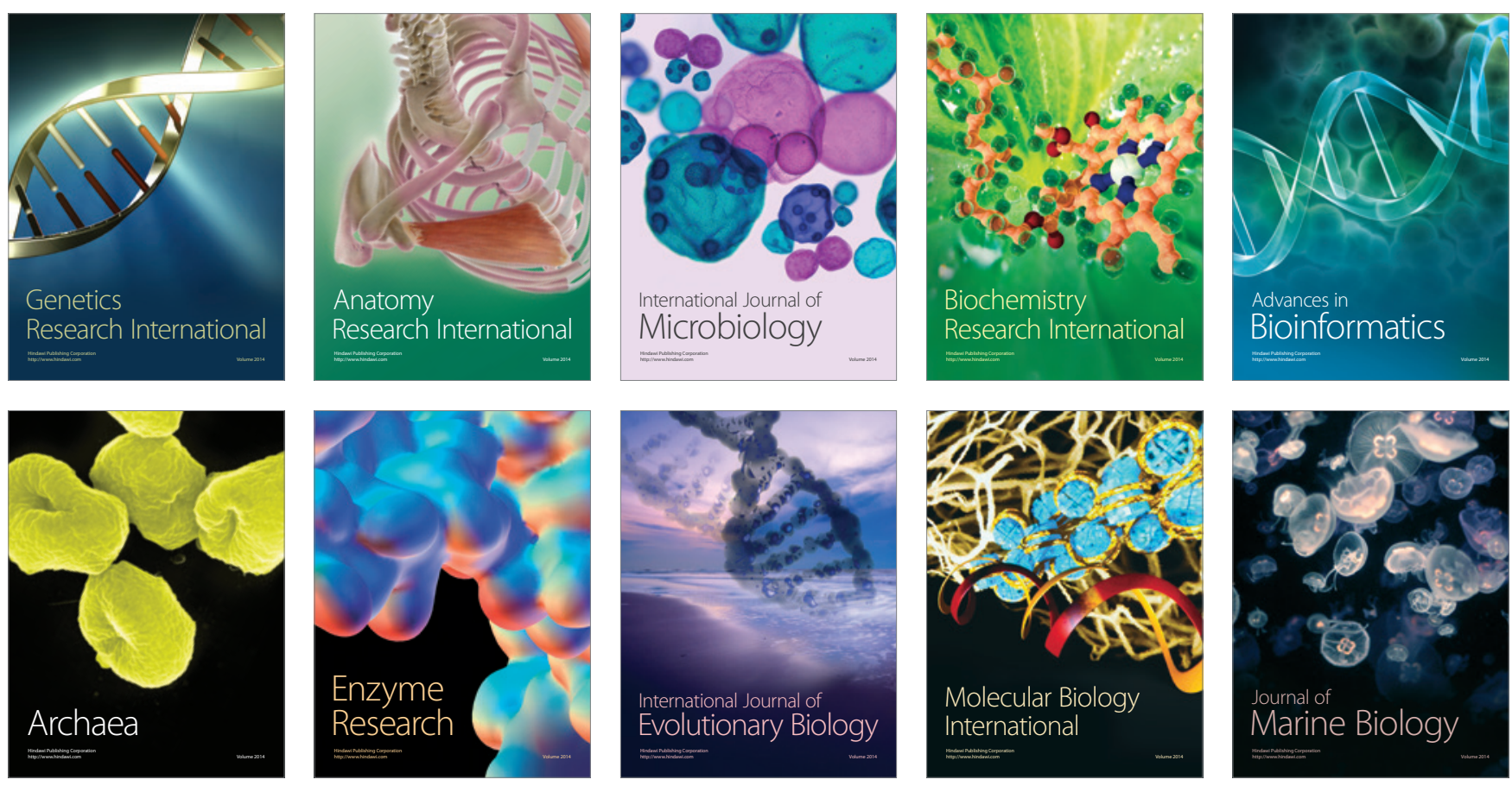